Elena Sira,

Ph.D., University of Presov, Slovakia

(iD) ORCID ID 0000-0002-9907-1372,

email: elena.sira1@gmail.com

Ryszard Pukala,

Ph.D., Bronisław Markiewicz State Higher School of Technology and Economics in Jarosław, Poland

iD ORCID ID 0000-0002-2943-8482

email: ryszard.pukala@interia.pl

Correspondence author: elena.sira1@gmail.com

\title{
MANAGEMENT OF AGRICULTURE INNOVATIONS: ROLE IN ECONOMIC DEVELOPMENT
}

Abstract. Agriculture has a significant economic position in each country, either historically or in terms of importance. Without the products of agriculture, there could be no life. That's the reason to analyze this industry. This industry is now, in the current global world, affected by new trends and new competition on the market. New management, innovations, and other challenges that occurred in this sector. It must face new threats. Primarily, significant changes in the global world environment significantly affect this sector. Firstly, through the volume of crop production, respectively, non-production due to substantial climate changes. Secondly, due to stricter market conditions and its current regulation. Changes in these areas have a significant impact not only on the development in the agricultural sector itself but also on the development of the economy as a whole. Today, competitiveness plays a significant role in the world, as well as in agriculture. This paper summarizes the findings from the area of agriculture, nowadays trends in this sector, innovations. It analyses the competitiveness in this sector, which is characterized by its specific features. Then it summarizes the findings and central thesis about Common Agricultural Policy and its instruments. Another part of this article is dedicated to an important topic - innovation in agriculture. Agricultural innovation is seen as a co-evolutionary process because it combined technological, social, economic, and institutional changes. The main aim of the article is to identify the impact of agriculture on the economic development of the Slovak Republic economy and to show the possibilities for innovation implementing into this sector. The selected indicators will analyze the description of the position of this sector in the past and today.

The typical indicators for the agricultural sector were set. Methodological tools of the research methods were analyzing statistical purposes as a regression model, and p-value. Through a regression model, we would like to know what is the dependence of crop and livestock productions on the GDP of agriculture. Finally, improvements to the current state will be suggested. To gain the representative data, more than 20 years of research were set. The object of study is the Slovak republic. The position of agriculture within this country was identified. The article shows the results of the verification of dependencies between indicators in the agricultural sector, which showed that statistical significance is assumed, which, of course, is confirmed both in crop and livestock production. The systematization of domestic and foreign scientific studies and approaches to answering problems in the management of agricultural innovations and the low share of agriculture on GDP makes it possible to create suggestions for the innovative solutions in agriculture in Slovakia.

Keywords: agriculture, management, innovation, crop production, livestock production, Slovak Republic

Introduction. Agriculture has an indispensable role in the life of each of us. In the past, the primary purpose of agriculture was mainly food production. This has recently been transformed with the added value of multifunctionality. This trend, which is characteristic of agriculture and the development of rural settlements, is legally ensured by the Common Agricultural Policy (CAP) and the new EU rural development policy. (Knickel et al., 2009)

Cite as: Sira, E., \& Pukala, R. (2020). Management of agriculture innovations: Role in Economic Development. Marketing and Management of Innovations, 2, 154-166. http://doi.org/10.21272/mmi.2020.2-11 
Agriculture belongs to the oldest sectors of every economy. It is a crucial sector, as its role is to provide nutrition to the population. The main factor of production is the land, which is limited in size. It is a factor that cannot be restored, and its size is constant. (Kuzevicova et al., 2013) Thus, increasing agricultural production is only done by using land more efficiently by using the latest knowledge. In many countries, agriculture using elements of innovation is a significant driver of the country's economic development. (Ayodele, Innocent and Garba, 2019) The benefits of agriculture have been immense. Agriculture was one of the leading sectors of the economy of the country for the years. (Popov, 2017).

Currently, the development of any sector involves respecting the principles of sustainability, which means economic, social, and environmental development. Moreover, farming is a critical field for ensuring sustainable development. Environmental issues are gaining growing importance in providing more significant economic growth. Globalization and urbanization affect lifestyle and consumer behavior. Sustainable economic development involves the promotion of environmentally friendly policies, at any financial level, and the transformation of consumption and production so that human and economic activities support a sustainable society. (Aceleanu, 2016)

According to an essential role of agriculture within the country's economy, the main aim of the article is set. It means to identify the impact of agriculture on the economic development of the Slovak Republic economy. And also to show the possibilities for innovation implementing into this sector. Every country is prosperous when it is competitive. This also applies to industry conditions.

Competitiveness is associated with the application of products in the domestic and foreign markets of organizations, integration groups, or countries to successful participation in the exchange of products of material or immaterial nature at different levels of trade. The essence of competitiveness is to obtain an advantage in the sales market. Competitive advantage is an opportunity of the economic subject to gain a more significant market share or other benefits as a market leader. (Simo, Mura and Buleca, 2016).

The authors Jambor and Babu (2017) find the nine key factors for countries' competitive performance, which should be seen in global agricultural markets. They are:

- $\quad$ Create efficient institutions - Effective institutions that lay down precise rules for farmers are a definite asset for the development of the sector. By setting clear standards, a transparent functioning of the sector and its components is ensured. It is also possible to avoid various negative phenomena, such as a waste of resources.

- Invest in physical infrastructure - Appropriate transport infrastructure must be provided for agricultural development. Innovative solutions used, e.g., on the railways or in the storage and use of other services, are a vital element of effective agricultural management.

- $\quad$ Create a conducive macroeconomic environment - The main element that ensures competitive agriculture are macroeconomic indicators and their development. If the development of these indicators is stable, it also leads to an increase in the competitiveness of agriculture. In ensuring a stable macroeconomic environment, it is necessary to pay attention to several factors affecting stability and to avoid significant changes in monetary or fiscal policy.

- Invest in health and education - To increase the competitiveness of the agricultural sector, it is necessary to pay attention to human capital. The performance of workers, their experience, and knowledge will be reflected in the resulting figures of the sector. For this reason, it is crucial to ensure people's erudition and adequate education. This work is carried out mostly outside, so it is essential to pay attention to the health of workers.

- Improve market access - Access to resources is a vital issue for every sector, including agriculture. Securing the necessary inputs, such as fertilizers, chemicals, seeds, etc. is a crucial point for increasing competitiveness. That farmer, who has access to these critical factors as well as the necessary financial resources, has an absolute advantage over other market players. 
- $\quad$ Create efficient land markets - There is no doubt that land is the primary source of agricultural production. Therefore, it is important for countries how the soil is represented in the area, or what is the distribution of the soil. In the case of insufficient access to land and poor working practices, the country moves down among the most successful competitors. Also, farmers' negligence in respecting the protection of the environment is usually affected by a financial penalty, which in turn harms the overall management of the entity.

- Improve agricultural risk management - Risk management is an essential part of farmers. It is also a significant problem. This is because weather instability and significant fluctuations in individual years affect the harvest and change its real volume compared to the planned one. And the profitability in this sector is significantly linked to the grain. In this case, the government, in collaboration with the agricultural industry, must propose adaptive risk management strategies. It is also necessary to take into account and hedge against known climatic risks.

- Improve innovation and technology adoption - Current knowledge from research and development is crucial for agriculture. The use of experience from new technological innovations, advances in genetic research and plant breeding means a tremendous competitive advantage for this sector. The benefit is, e.g., reproduction of plants that better tolerate weather instability and thus ensure stable annual revenue. Therefore, an efficient research and development system is essential for these companies.

- Ensure sustainable management of natural resources - Natural resources are irreplaceable, and therefore special attention must be paid to their protection. Improvements in forestry and land management legislation increase competitiveness. The current trend in this area is to support afforestation efforts.

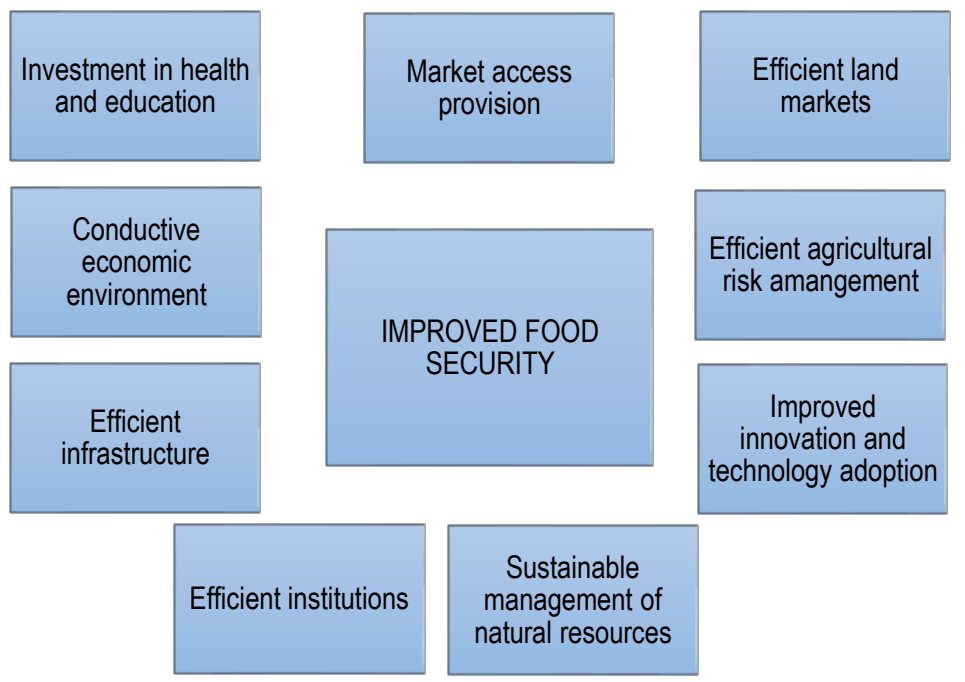

Figure 1. Factor affecting food security through agricultural competitiveness

Source: systematized by the authors based on (Jambor and Babu, 2017)

Literature Review. Agricultural practices determine the level of food production and, to a great extent, the state of the global environment. (Tilman et al. 2002) Agriculture is diverse and full of contradictions. (Adamisin et al. 2017) The importance of agriculture is not in its size and share in the total output of the economy. This sector performance is a relatively small share of the world economy but remains the central point of many people's lives. Life is not possible without the products of this sector. (Dobrovic et al. 2016), 
(Alston and Pardey 2014) Agriculture supplies much more than food for direct human consumption: it produces significant amounts of feed (for livestock), fuel (for transportation, energy production, including household kitchen fires), fiber (for clothing), and, increasingly, agricultural biomass used to produce a host of industrial chemical and material products. (Alston and Pardey 2014)

We can identify two critical characteristics of agriculture. The first is the production of goods that ensure human nutrition. (Diao et al. 2007) We can use the example to point out the importance and indispensability of agriculture. E. g. the production of $1 \mathrm{~kg}$ of meat may require between 3 and 10 kilograms of grain. Over the last 40 years, global meat production per capita has increased by more than $60 \%$ (Tilman et al. 2002). Thus, we see high pressure on crop production.

The second is the fact that agricultural production combines human labor and effort (Kotulic et al. 2017) with natural resources such as land and agroecological assets. In this respect, it is a highly demanding industry, where it is tough to predict outputs with certainty. Agricultural production is also significantly affected by weather, which is difficult to predict and hedge against its harmful effects. Early development theorists believed that since natural resources are assumed to be freely available, agriculture could grow independently of other economic activities. In reality, however, the dependence of agriculture on fixed land supply meant that its expansion was limited, which means that agricultural production cannot increase proportionately with the increased labor supply under the technology (i.e., agriculture has a reduced return). Classical theorists have found that most developing countries consist of «dual» economies. From this point of view, labor productivity in agriculture is lower than in industry, and therefore the development requires the transfer of agricultural labor to non-agricultural sectors. (Diao et al. 2007)

The efficient functioning of the agricultural sector is an essential part of the efficient operation of each country's economy. The agricultural sector has played a particularly important role in the development of the integration process in Western Europe from the outset. In the period after the Second World War, countries were unable to ensure their agricultural production, and there was a need to create an effective mechanism to ensure a smooth supply of food. It follows that the main reasons for the establishment of the Common Agricultural Policy were mainly economic and political. The standard agricultural policy is one of the most significant consequences of the European integration process; it is also the best-known activity of the EU and probably also the most discussed. This policy has taken into account the specific features of the agricultural sector. Unlike industrial production, where it is possible to determine relatively precisely the volume of production in the case of the agricultural output, it is different. Agricultural production is strongly influenced by natural conditions that cannot be anticipated and cannot be protected against them. (Kravcakova Vozarova and Danova, 2017)

Kucerova (2010) argues that the need for a revision of agrarian policy was evident, as the cost of financing it grew faster than the volume of agricultural production. An important aspect was also the fact that the responsibility of funding lay with only a few countries.

The solution to the MacSharry reform was, on the one hand, to link the fall in price subsidies, on the other, to ensuring adequate farmers' incomes. It was a combination of the following instruments (Kucerova 2010, Lebiedzik and Tvrdon 2007):

- $\quad$ reducing intervention and threshold prices, which was also a commitment in the Uruguay Round itself;

- the introduction of compensatory payments to cut production, ensuring a stable income depending on the size of the cultivated land or the size of the herd; the new support system was based on the fact that these compensations will be paid per hectare and the amount of payment will vary from region to region, depending on the average productivity in those regions;

- $\quad$ orientation on limiting production volumes, including rotating or permanent eel;

- $\quad$ support for early retirement (farmers over 55 years of age), if they allow for farm enlargement and hence more efficient production, by leaving their economy to another entity; 
- $\quad$ promoting alternative use of agricultural land such as afforestation, recreation, tourism, etc.

The main objective of the reform was to eliminate the differences between the internal and world prices of agricultural production by successive steps, using the above measures, thereby reducing export subsidies. (Kravcakova Vozarova and Danova, 2017)

At present, there is a need for constant cooperation between politicians and researchers. Continuous monitoring of new trends and their current connection to the specific needs of the entity are vital points of success. Top-down solutions, e.g., Increasing food security (Sanchez and Swaminathan, 2005) does not guarantee success without bottom-up efforts to find solutions suitable for specific places. With suggestions from below, we can evoke the interest of scientists and then apply their proposals (top-down) to the conditions in a particular industry. Therefore, the involvement of scientists in addressing specific practical requirements is crucial. (DeFries et al. 2012)

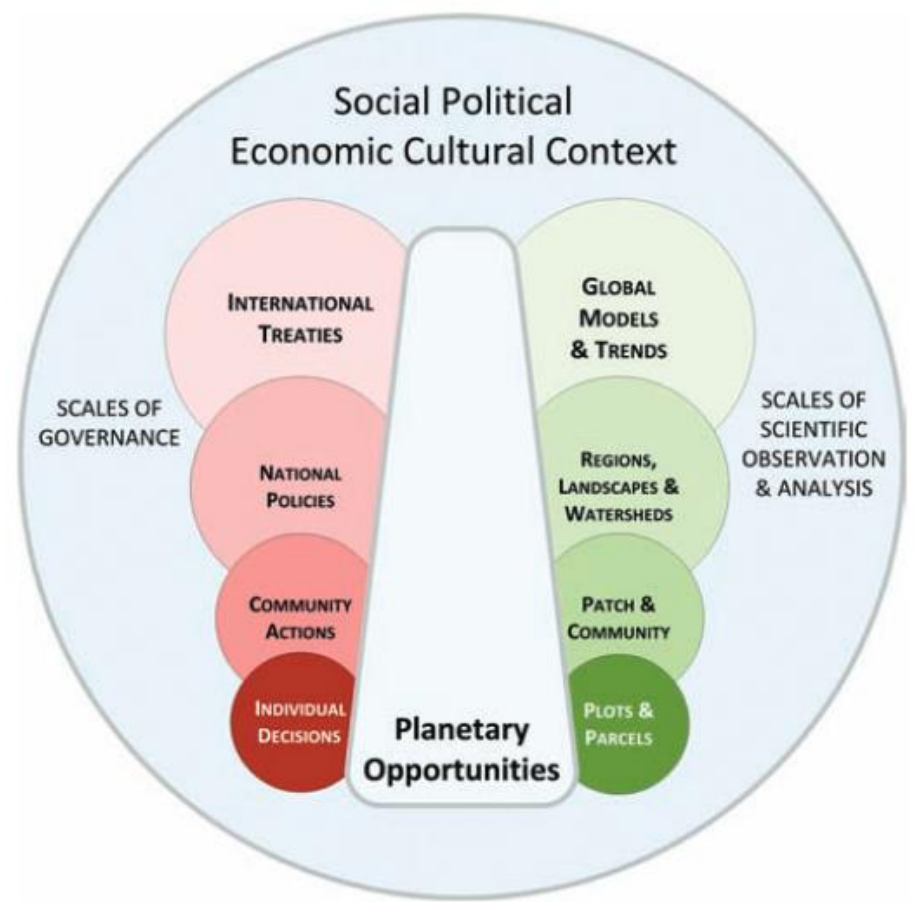

Figure 2. Social, political and cultural context

Source: systematized by the authors based on (DeFries et al., 2012)

Decision-makers are influenced by various findings from several areas and analyzes. Their proposals are often based on the latest research and reflect the latest innovations, but may not be the most appropriate solution for a particular entity. This is because they do not take into account individual differences, only the latest global knowledge. (DeFries et al., 2012)

Innovations in agriculture. The term «innovation» originates from the Latin word «innovatio», which means to renew, to make new, to change. In the economic literature, the term «innovation» characterizes the application of research and development results aimed at improving the production process, economic, legal, and social. Innovation is generally understood as successful production, assimilation, and the use of innovations in the economic and social fields. Innovation can take various forms, such as working in 
new ways, developing new products and services, or adapting a proven approach to unique circumstances. (Stefekova and Moravcíkova, 2016)

Agricultural innovation is seen as a co-evolutionary process, i.e., combined technological, social, economic, and institutional change. (Pukala, 2016) Therefore, production and exchange of (technical) knowledge are not the only prerequisites for innovation. Several additional factors play a crucial role, such as policy, legislation, infrastructure, funding, and market developments. Agricultural innovation is hence not just about adopting new technologies. It also requires a balance amongst new technical practices and alternative ways of organizing. (Klerkx et al., 2012) This process faces potential risks that can be reduced by appropriate education, as mentioned by Knight, Weir, and Woldehanna (2003).

The literature on agricultural innovation processes indicates an evolution from theoretical perspectives to co-innovation approaches. Co-innovation is an iterative process that brings together knowledge from many stakeholders to support changes in technology, markets, regulations, and other practices that support the commercialization and implementation of the experience to improve production. (Vereijssen et al., 2017).

One way in which we can precisely monitor the impact of the use of innovation in agriculture in recent years is to monitor the use of information technology in this sector. The reproductive process in agriculture is influenced by several factors that are stochastic, and their influence is difficult to quantify. Simulation is of great importance in stochastic methods of operational analysis. Simulation methods are one of the useful tools suitable for the study and rationalization of the management of complex processes and systems (Hennyeyova, 2012), including agricultural operations. The condition for the effective use of any quantitative method in the field of practical decision-making and management is an understanding of the underlying assumptions and starting points of the selected process and evaluation of its area of applicability in specific conditions.

Based on the results of Hennyeyova research (2012), in Slovak agricultural enterprises, the references of agricultural enterprises about the benefits of using ICT have shown that the most significant benefit is considered to be flexible communication and sufficient access to information. The least interest is deemed to be greater competitiveness and lower costs. Businesses are increasingly aware of the need for and benefits of ICT. If a company wants employees to work as efficiently as possible, they must work with information technology. In half of the surveyed companies $(50.30 \%)$ use computers from $0-20 \%$ of employees. The local computer network is used by $64.85 \%$ of companies in the agricultural sector. Most enterprises using the local computer network are among food enterprises $(66.67 \%)$, followed by agrarian cooperatives $(65.22 \%)$ and enterprises of other agricultural focus $(60.71 \%)$.

Effective management of agriculture can now only be achieved with information and communication technologies and the use of optimization processes. Enterprises that respond flexibly to progressive changes in the information field have a competitive advantage over others. This fact can be seen both between companies and between sectors in different countries, too.

The broader view on agricultural innovation, seen as the result of multiple interactions between components of farming systems, supply chains, and economic systems, policy environments, and societal systems, is reflected in the idea that innovation is an outcome of «agricultural innovation systems.» The thinking about agricultural innovation systems can be seen as the most recent in a family of systems approaches. The perspective is still in development. (Klerkx et al., 2012)

Agriculture is a specific sector where product innovation often means improving its characteristics. However, the specificity is that only based on the latest research findings, long-term research, and modification of genetic information and breeding can «product» innovation take place. Besides, it is a very time-consuming process compared to innovations in other sectors.

Methodology and research methods. Agriculture has a dominant, historical, and very significant impact on the economy of each country. For this reason, agriculture was selected for analysis. 
The main aim of the article is to identify the impact of agriculture on the economic development of the Slovak Republic economy and to show the possibilities for innovation implementing into this sector.

The impact of industry on the economy of the country is examined and verified by various indicators. We have selected the following symbols for the analysis:

- GDP of agriculture as \% of the total GDP of the country,

- gross agriculture output,

- $\quad$ gross crop production (CP),

- gross livestock production (LP).

For the analyzes, the period of $1995-2018$ was chosen. The period is over 20 years to gain exact results from the analyses. During this period is shown, how was the position of agriculture changed, and what are the challenges in this sector for the future.

The set hypotheses are:

Hypothesis 1: We assume that there are statistically significant differences between gross agriculture output and crop and livestock productions

$\mathrm{H}_{0}=0$

$\mathrm{H}_{1} \neq 0$

Hypothesis 2: We assume that there are statistically significant differences between GDP and crop and livestock productions

$\mathrm{H}_{0}=0$

$\mathrm{H}_{1} \neq 0$

We used a multiple regression model to assess dependence, and the calculations were done in the Statistica 14 statistical program.

Results. Agriculture in the Slovak Republic is an important part of the country's economy. Its main task is to ensure the nutrition of the population. The food industry has a long tradition based on quality production. The food industry is directly linked to primary agricultural production, provides necessary food production, services, creates jobs, has a significant impact on the development of regions. The primary task is, above all, to ensure the nutrition of the population.

But even this sector does not avoid problems. One of the most severe obstacles to the growth and development of the food industry was the arrival of foreign retail chains in the Slovak Republic, which contributed mainly to a significant decline in the share of domestic food products in the local market. (Stefekova and Moravcíkova, 2016) Consumers themselves also contributed to the decrease in sales of domestic production, exchanging domestic food for ethnic cuisine, often of lower quality but also more economical price. Another negative that affects the food industry is the obsolescence of production technologies, which are highly energy-intensive and thus cause insufficient use of production capacity. There are no technological innovations necessary for the growth and development of the food industry. And companies are not ready to handle technological innovation without the support of external sources. The negative aspects of the food industry may also include the insufficient connection of the production area of the food industry with the results in the field of science and research of the food industry.

Let's have a look at the performance of the agriculture sector across the selected indicators. Gross domestic product is a very often used macroeconomic indicator, which represents the level of the economy. The share of agriculture in GDP was different in single years, or it could be said that it had a growing but predominantly rather fluctuating trend. After the EU accession in 2004, the agriculture in Slovakia recorded a positive economic result every year, as we can see below and in Chrastinova and Burianova (2012), too.

Figure 3 shows the development of the share of the agricultural sector on GDP. The share of agriculture is volatile, with not large fluctuations. Agriculture had the largest share in GDP in 1995, in the amount of over $5 \%$. In 1998, the share of agriculture in GDP fell slightly but increased in 2001. On the 
contrary, the lowest values were in 2010, in the amount of 2,55\%. The GDP of the Slovak Republic despite the decline in the agricultural sector, was steadily increasing. The volume of GDP in agriculture also continued to grow until 2008, but its increase was not as significant as the increase in GDP itself. Actually, in 2018 , is the amount of this indicator very similar to the value of 2010 . Today, it is $2,59 \%$.

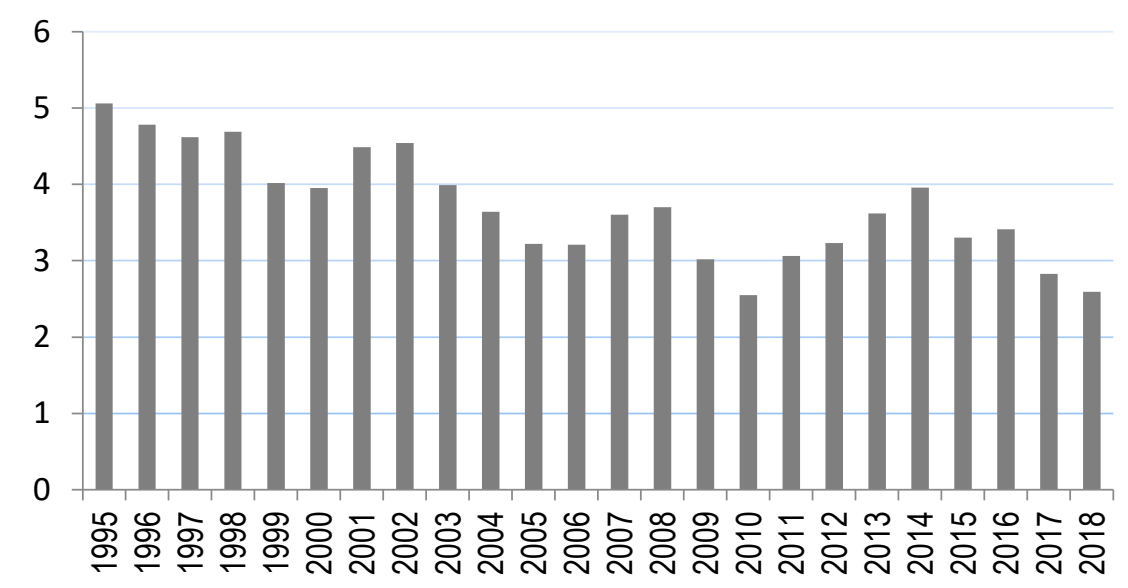

Source: developed by the authors.

The share of agriculture on GDP tells us about the importance of agriculture as a sector of the economy. However, to get to know the development of agriculture in detail, it is necessary to focus on the absolute values of this sector. Therefore, Figure 4 shows the evolution of gross agricultural output in the years 1995-2018. This gross agrarian output is analyzed in general and then divided into crop and livestock production.

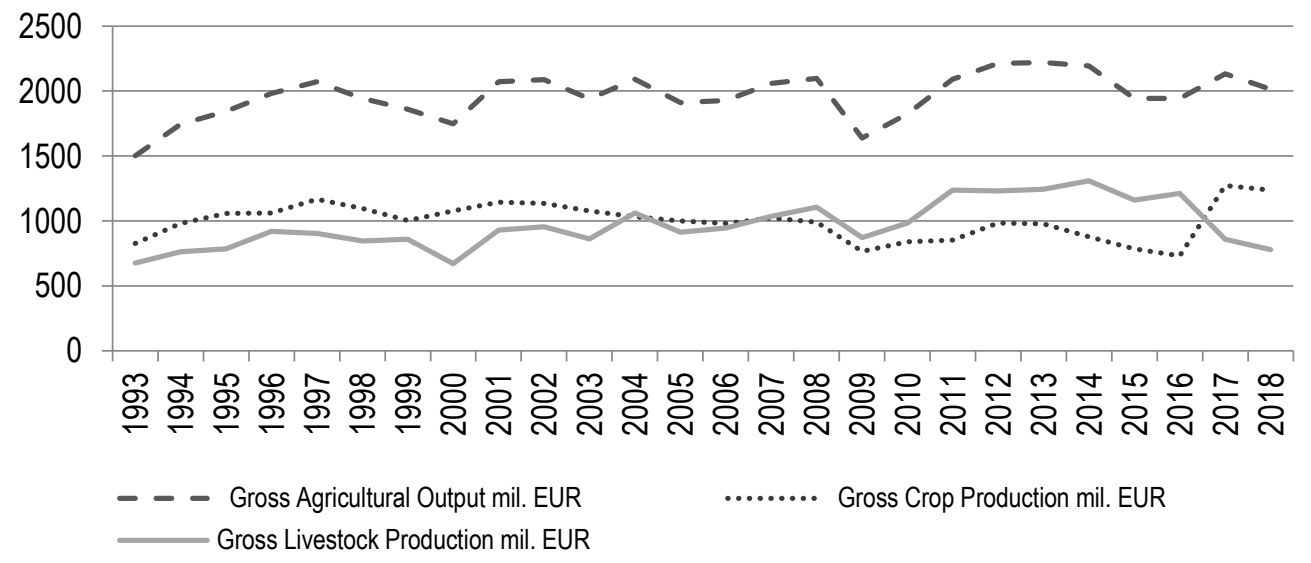

Source: developed by the authors.

Figure 4. Gross agricultural output 
The overall development of gross agricultural production in Slovakia is without significant changes. There is also no growing trend in it. With major or minor modifications, its volume is around 2000 mil. Eur per year. It is clear that in Slovakia, innovative solutions are not being introduced in the agricultural sector, which would help to change gross agricultural production radically. Innovative solutions adopted by small farmers are hardly reflected in the overall development. Therefore, innovation and progress must be widely accepted. This is the only way to reflect the overall performance.

There are two variables, namely gross crop production and total livestock production. Based on these variables, their relationship with gross agricultural output is analyzed.

Hypothesis 1: We assume that there are statistically significant differences between gross agriculture output and crop and livestock productions

$\mathrm{H}_{0}=0$

$\mathrm{H}_{1} \neq 0$

To verify the relationship dependence, it is necessary to perform the Correlation matrix function. After performing this function, we find out the following values:

- the gross crop production is $r=0.7682$, which indicates a relatively strong relationship,

- gross livestock production is $r=0.3130$, which means a relatively weak relationship.

It follows, therefore, that gross crop production represents a high strength of a relationship, and gross livestock production represents a small strength of a relationship. However, based on this, we reject $\mathrm{HO}$ and accept hypothesis $\mathrm{H} 1$.

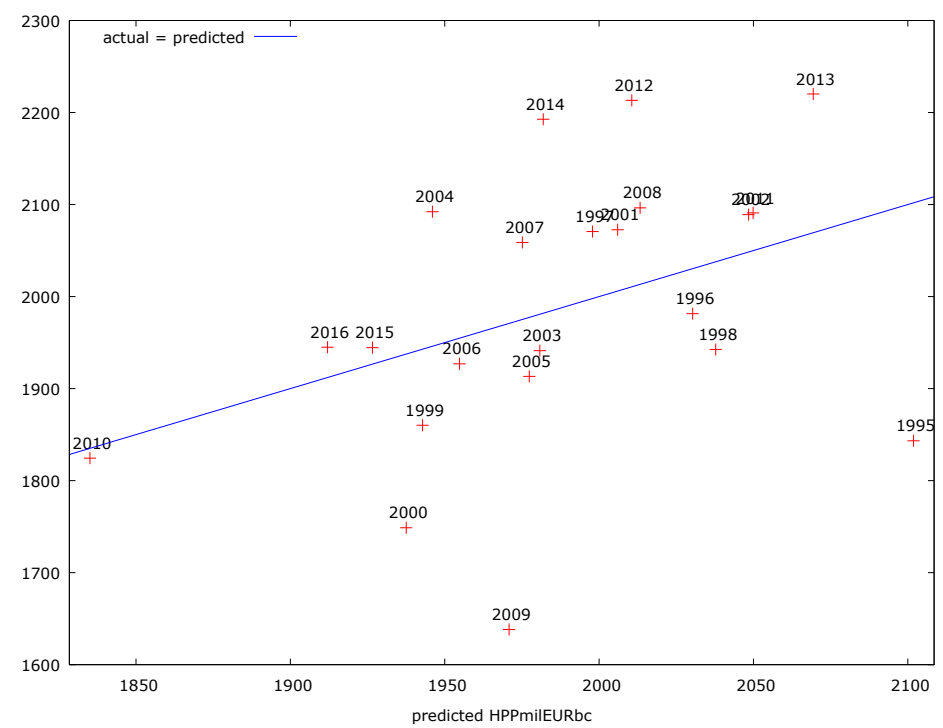

Figure 5. Prediction of Gross agricultural production

Source: developed by the authors.

Crop and livestock productions should also have a significant impact on agricultural GDP. We have, therefore, examined whether crop and livestock productions are affecting the agricultural GDP.

Hypothesis 2: We assume that there are statistically significant differences between GDP and crop and livestock productions

$\mathrm{H}_{0}=0$

$\mathrm{H}_{1} \neq 0$ 


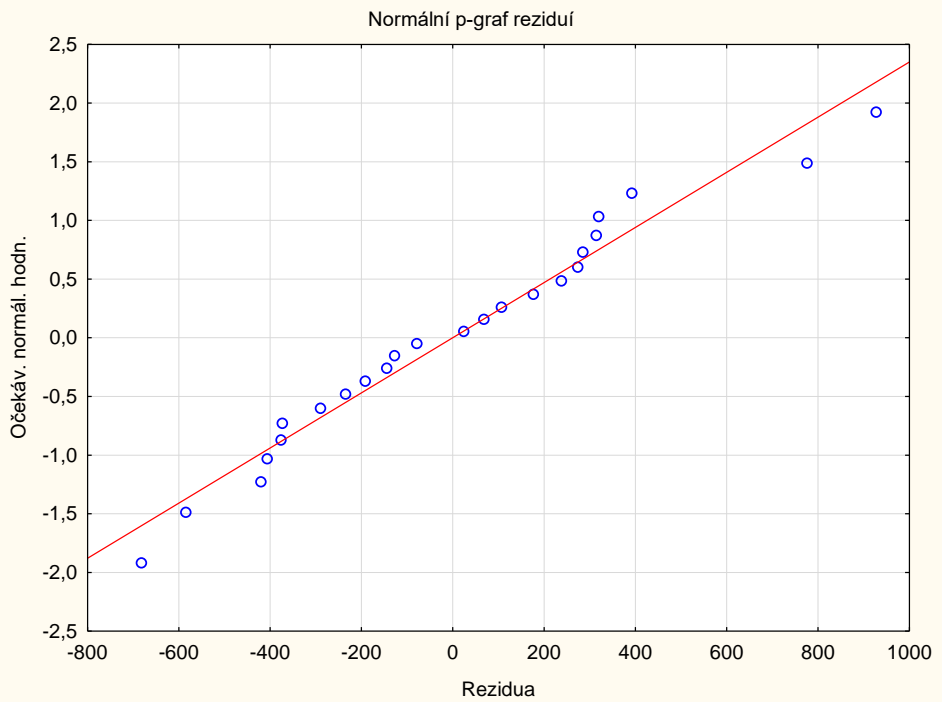

Figure 6. Normal $P$ residue graph

Source: developed by the authors.

According to the Normal $p$ residue graph (Figure 6), there is seen the normal distribution. Our dependent variable is yi $=\mathrm{GDP}$, and the independent variable representing the coefficients $\beta 1$ is Crop production (CP), and $\beta 2$ is Livestock production (LP). Furthermore, it is the coefficient e, describing the error. According to results from the regression analyses done in program Statistica 14, writing the estimated multiple regression model as follows:

$$
G D P=-941,453+0,207 C P+2,666 L P+e
$$

The value of the correlation coefficient is 0.7406 , which gives us a strong relationship between the variables.

The verification of hypotheses is performed through $P$ values. The P-value of crop production is 0.7886 . The P-value of livestock production is 0.0003 . These results show that we have statistical evidence that crop production and livestock production are essential. This value is in case of livestock production less than 0.05 , so $\mathrm{H} 0$ rejects and accepts the hypothesis $\mathrm{H} 1$.

An important factor is the coefficient of determination R2, which tells us about the variability of the GDP of agriculture. This figure has the term «R-squared,» and its value is 0.5485 , representing $54.85 \%$ of the variability share in the agricultural GDP.

Conclusions. Selected factors analyzed the agricultural sector in the Slovak Republic. Here are shown the main results resulting from made analyses and try to give some recommendations for the future to improve the current position of this sector.

The two hypotheses were verified. First, were set two variables, namely gross crop production and gross livestock production. Based on these variables, their relationship with gross agricultural output was analyzed. The gross crop production represents a high strength of a relationship, and gross livestock production represents a small strength of a relationship. However, based on this, we reject $\mathrm{H} 0$ and accept hypothesis $\mathrm{H} 1$. The second hypothesis analyzed the agricultural GDP dependency on crop and livestock productions. The results show that we have statistical evidence that crop production and livestock 
production are essential. This value is in case of livestock production less than 0.05 , so $\mathrm{H} 0$ rejects and accepts the hypothesis $\mathrm{H} 1$.

The share of agriculture in the economy of the Slovak Republic was quite low throughout the period. This share depends on agricultural production. Many companies in the agricultural industry make a lot of effort to maintain their market share and ensure their future functioning. It is precisely for market sustainability, increasing competitiveness, and securing future developments that innovation is a necessary factor. Likewise, the challenges facing the agricultural sector underline the urgent need for innovation, precisely to improve competitiveness and market sustainability. In this area, there is scope to take into account the latest scientific knowledge, innovations, and these have been used to improve production processes. In this way, the management of innovation can contribute to improving the position of agriculture in the Slovak economy.

Some changes need to be made to raise the level of agriculture. Finally, we offer several innovative solutions to improve agricultural management. They are:

- focus on small farms,

- the direct connection between the seller and the buyer,

- eco-innovation,

- $\quad$ alternative sources of financing for agriculture.

One possibility is to focus more on smaller farms and support their activities. Small farms are more flexible in adapting to market requirements. But on the other hand, they also have less bargaining power on the market. As we can see on an example of berry farms in Europe (Greblikaite, Ispyrian, Montvydaite, 2019), a real challenge for the producers is to utilise the tools of marketing better. Therefore, the products sold on the market is higher, a helps the company to be profitable.

Another way, how to increase the financial results of agriculture is to establish the direct link between producer and consumer, as shown by Fisher et al. (2012) By directly connecting the producer and the consumer, the whole agricultural sector will gain considerable benefits. On the one hand, the consumer will have more confidence in the products, as they are targeted, and on the other hand, we can increase sales. At the same time, if we can ensure more sales, the producer does not have to go below cost, and we also avoid wasting unsold food. This recommendation takes advantage of today's marketing innovation. Following the current trend of ecological trading, this innovative idea could be successful and accepted among buyers. Now is the right time to apply it in practice. This is also justified by the fact that various marketing teams are currently involved in promoting a healthy lifestyle and protecting the environment.

At present, eco-innovations are receiving the focus. They are considered a key, according to Europe's future. For this reason, European Union politicians are also receiving increased attention from them. Ecoinnovation offers an opportunity for small and medium-sized enterprises, how they can contribute to sustainable development, and the resulting more competitive economy. These eco-innovations are therefore seen as a possible combination of 2 policies, economic and environmental. (Lesakova, 2019). It is the other possibility, how can be Slovak agriculture stronger.

Otherwise, we must take into account the possibility of financing innovation in agriculture. There are some opportunities from the EU (Pukala and Petrova, 2019). The chances of EU financial support for innovative projects in the Slovak Republic provide an essential boost for the introduction of new innovative technologies into the production process, which can significantly contribute to improved competitiveness of agricultural subjects in the future. (Van der Meulen, Van Asseldonk and Ge, 2016).

Consumption of agricultural production has long been based on demographic indicators. If we want to improve the performance of this sector, we must take into account the new global trends, innovations and use people's knowledge to benefit their work outputs. This sector is highly specific to the unpredictability 
of the environment, so the only way to indicate improvements is to use the current scientific conclusions for the whole industry.

Author Contributions: Conceptualization, E. S. and R. P.; methodology, E. S.; software, R. P.; validation, E. S., and R. P.; formal analysis, R. P.; investigation, E. S.; resources, E. S.; data curation, E. S. and R. P.; writing—original draft preparation, E. S.; writing—review and editing, E. S.; visualization, E. S.; supervision, E. S.

\section{References}

Aceleanu, M. I. (2016). Sustainability and competitiveness of Romanian farms through organic agriculture. Sustainability, 8(3), 245. [Google Scholar] [CrossRef]

Adamisin, P., Kotulic, R., \& Vozarova, I. K. (2017). Legal form of agricultural entities as a factor in ensuring the sustainability of the economic performance of agriculture. Agricultural Economics, 63(2), 80-92. [Google Scholar] [CrossRef]

Alston, J. M., \& Pardey, P. G. (2014). Agriculture in the global economy. Journal of Economic Perspectives, 28(1), 121-46. [Google Scholar] [CrossRef]

Ayodele, O. J., Innocent, I. O., \& Garba, S. J. (2019). Innovation as a Mediating of Relationship Between Internal and External Environment in Agribusiness Performance. Marketing and Management of Innovations, 1, 196-207. [Google Scholar] [CrossRef]

Chrastinova, Z., \& Burianova, V. (2012). Economic efficiency of Slovak agriculture and its commodity sectors. Agricultural Economics, 58(2). [Google Scholar]

DeFries, R. S., Ellis, E. C., Chapin III, F. S., Matson, P. A., Turner, B. L., Agrawal, A., ... \& Lambin, E. (2012). Planetary opportunities: a social contract for global change science to contribute to a sustainable future. BioScience, 62(6), 603-606. [Google Scholar] [CrossRef

Diao, X., Hazell, P. B., Resnick, D., \& Thurlow, J. (2007). The role of agriculture in development: Implications for Sub-Saharan Africa (Vol. 153). Intl Food Policy Res Inst. [Google Scholar]

Dobrovic, J., Koraus, A., \& Dancisinova, L. (2016). Sustainable economic development of Slovakia: factors determining optimal tax collection. Journal of Security \& Sustainability Issues, 5(4). [Google Scholar]

Fischer, A. R., Beers, P. J., van Latesteijn, H., Andeweg, K., Jacobsen, E., Mommaas, H., ... \& Veldkamp, A. T. (2012). Transforum system innovation towards sustainable food. A review. Agronomy for sustainable development, 32(2), 595-608. [Google Scholar] [CrossRef]

Greblikaite, J., Ispiryan, A., \& Montyydaite, D. (2019). Development of Berry Farms in Europe: Organisational and Management Issues. Marketing and Management of Innovations, 2, 141-159. [Google Scholar] [CrossRef]

Hennyeyova, K. (2012). Informacne technológie a optimalizacne procesy v podnikoch agrosektoru. Nitra: SPU, 1-5. [Google Scholar]

Jambor, A., \& Babu, S. C. (2017). Competitiveness of global agriculture: Policy lessons for food security: Synopsis. Intl Food Policy Res Inst. [Google Scholar]

Klerkx, L., Van Mierlo, B., \& Leeuwis, C. (2012) Evolution of systems approaches to agricultural innovation: concepts, analysis and interventions. In Farming Systems Research into the 21st Century: The new dynamic (pp. 457-483). Springer, Dordrecht. [Google Scholar] [CrossRef]

Knickel, K., Brunori, G., Rand, S., \& Proost, J. (2009). Towards a better conceptual framework for innovation processes in agriculture and rural development: from linear models to systemic approaches. Journal of Agricultural Education and Extension, 15(2), 131-146. [Google Scholar] [CrossRef]

Knight, J., Weir, S., \& Woldehanna, T. (2003). The role of education in facilitating risk-taking and innovation in agriculture. The Journal of Development Studies, 39(6), 1-22. [Google Scholar] [CrossRef]

Kotulic, R., Adamisin, P., Vozarova, I. K., \& Vavrek, R. (2017). The Impact of Management Skills of Agricultural Entities in Relation to Economic Efficiency and Natural-Climatic Conditions in Slovakia. Journal of Environmental Management \& Tourism, 8(1 (17)), 92. [Google Scholar]

Kravcakova Vozarova, I., \& Danova, M. (2017). Developmental aspects of shaping the EU Common Agricultural Policy in the context of its individual reforms. Acta academica karviniensia, 17(2), pp. 88-99. [Google Scholar] [CrossRef]

Kucerova, I. (2010). Economic policies in the context of the development of the European Union. Praha: Karolinum. [Google Scholar]

Kuzevicova, Z., Gergel'ova, M., Nascakova, J., \& Kuzevic, S. (2013). Proposal of methodology for determining of potential residual biomass for agriculture and forestry in Slovak republic. Acta Montanistica Slovaca, 18(1). [Google Scholar]

Lebiedzik, M. \& Tvrdon, M. (2007). Economic policies of European Communities - origin, development and present. Karvina: Slezska univerzita v Opave. [Google Scholar]

Lesakova, L. (2019). Small and Medium Enterprises and Eco-Innovations:Empirical Study of Slovak SME's. Marketing and Management of Innovations, 3, 89-97. [Google Scholar] [CrossRef] 
Popov, А. (2017). Assessment of land fragmentation of agricultural enterprises in Ukraine. Економічний часопис-XXI, 164(34), 56-60. [Google Scholar] [CrossRef]

Pukała, R. (2016). Use of neural networks in risk assessment and optimization of insurance cover in innovative enterprises. Economics and Management, 8(3), 43-56. [Google Scholar] [CrossRef]

Pukala, R., \& Petrova, M. (2019). Application of the AHP Method to Select an Optimal Source of Financing Innovation in the Mining Sector. In Web of Conferences (Vol. 105, p. 04034). EDP Sciences. [Google Scholar] [CrossRef]

Sanchez, P. A., \& Swaminathan, M. S. (2005). Cutting world hunger in half. Science, 307(5708), 357-359. [Google Scholar] [CrossRef

Simo, D., Mura, L., \& Buleca, J. (2016). Assessment of milk production competitiveness of the Slovak Republic within the EU27 countries. Agricultural Economics, 62(10), 482-492. [Google Scholar] [CrossRef]

Stefekova, P., \& Moravcíkova, D. (2016) Inovacie $v$ agropotravinarstve. In: International scientific days The Agri-Food Value Chain: Challenges for Natural Resources Management and Society, SPU, Nitra. pp. 227-233

Tilman, D., Cassman, K. G., Matson, P. A., Naylor, R., \& Polasky, S. (2002). Agricultural sustainability and intensive production practices. Nature, 418(6898), 671. [Google Scholar] [CrossRef]

Van der Meulen, H., Van Asseldonk, M., \& Ge, L. (2016). Adoption of innovation in European agriculture. FLINT Deliverable D, 5. pp.23.

Vereijssen, J., Srinivasan, M. S., Dirks, S., Fielke, S., Jongmans, C., Agnew, N., ... \& Brazendale, R. (2017). Addressing complex challenges using a co-innovation approach: Lessons from five case studies in the New Zealand primary sector. Outlook on Agriculture, 46(2), 108-116. [Google Scholar] [CrossRef]

Олена Сіра,

Ph.D., Університет Пряшева, Словацька республіка;

Річард Пукала,

Ph.D., Державна вища технологічна та економічна школа ім. Кс. Броніслава Маркевича в Ярославі, Польща

Менеджмент інновацій в аграрному секторі: роль та місце в реалізації економічного зростання країни

Ця стаття узагальнює аргументи та контраргументи в межах наукової дискусії з питання місия і ролі інноваційного розвитку аграрного сектору в забезпеченні економічного зростання країни. Сільське господарство суттєво впливає на економічний розвиток країн, задаючи нові тенденції глобального рівня та створюючи додаткову конкуренцію на ринку. Визначено сутність нових моделей управління інноваціями в аграрному секторі. Розелянуто головні проблеми та перешкоди для інноваційного розвитку аграрного сектору. Встановлено основні загроз, які вливають не лише на сільськогосподарську галузь, а й економічний розвиток країни: скорочення обсягу виробництва продукції рослинництва у наслідок зміни клімату; суворіші ринкові умови, зростання конкуренції, а також сучасне державне регулювання. Основною метою даної статті $\varepsilon$ аналіз впливу сільського господарства на економічний розвиток Словацької республіки та визначення можливостей впровадження інновацій у досліджуваній галузі. Розв'язання поставленої мети в статті здійснено в наступній логічній послідовності: 1) систематизовано теоретичні напрацювання в області економічноі сутності інноваційної діяльності та розкрито специфіку застосування основних понять теорії інновацій в аграрному секторі; 2) проаналізовано конкурентоспроможність, сучасні тенденції та стримуючи чинники впровадження інновацій в аграрного сектору; 3) узагальнено результати ефрективності впровадження державної політики в аграрному секторі; 4) досліджено роль менеджменту інновацій в аграрному секторі, як процесу спільної еволюції технологічних, соціальних, економічних та інституціональних змін. Методичним інструментарієм проведеного дослідження стали методи регресійного аналізу. Об'єктом дослідження обрано аграрний сектор Словацької республіки, період дослідження становить 1983-2018рр. В статті представлено результати емпіричного аналізу, який дозволив визначити роль сільського господарства в економіці країни. Зокрема, у статті продемонстровано результати перевірки залежності між показниками діяльності сільськогосподарської галузі та здійснено припущення щодо існування статистичної значущості продукції рослинництва та тваринництва. На основі систематизації наукових напрацювань та підходів до вирішення проблеми управління сільськогосподарськими інноваціями та підвищення частки сільського господарства у ВВП, автори запропонували низку інноваційних рішень у сільському господарстві Словацької республіки з метою забезпечення економічного розвитку країни.

Ключові слова: сільське господарство, управління, інновації, продукція рослинництва, продукція тваринництва, Словацька республіка.

Manuscript received: 03.12.2019

(c) The author(s) 2020. This article is published with open access at Sumy State University. 